\title{
Exploring the impact of regional climate and local hydrology on Pinus sylvestris L. growth variability - A comparison between pine populations growing on peat soils and mineral soils in Lithuania
}

\author{
Johannes Edvardsson • Egidijus Rimkus • \\ Christophe Corona • Rasa Šimanauskienè • \\ Justas Kažys • Markus Stoffel
}

Received: 23 January 2015 / Accepted: 30 March 2015 / Published online: 14 April 2015

(C) Springer International Publishing Switzerland 2015

\begin{abstract}
Aims To compare growth variability of Scots pine (Pinus sylvestris L.) on different soil types, and to assess the potential of peat-soil pines for climatological and hydrological studies.

Methods We used extensive dendrochronological analyses to investigate temporal and spatial responses of pines growing on peat soils and mineral soils in three regions of Lithuania.

Results Significant correlations were observed between tree populations growing on similar soil types in different geographical regions, whereas synchronicity was absent between neighbouring stands growing on different soil types. At mineral soils, tree growth was significantly correlated with winter and early summer temperatures, whereas a more complex response was detected
\end{abstract}

Responsible Editor: Eric Paterson.

J. Edvardsson $(\bowtie) \cdot$ M. Stoffel

Dendrolab.ch, Institute of Geological Sciences, University of

Bern, Baltzerstrasse 1+3, CH-3012 Bern, Switzerland

e-mail: johannes.edvardsson@dendrolab.ch

E. Rimkus $\cdot$ J. Kažys

Department of Hydrology and Climatology, Faculty of

Natural Sciences, Vilnius University, M. K. Čiurlionio g. 21/

27, LT-03101 Vilnius, Lithuania

C. Corona

GEOLAB, UMR6042 CNRS and Blaise Pascal University,

Maison des Sciences de l'Homme 4, Rue Ledru,

F63057 Clermont-Ferrand Cedex 2, France in peat-soil trees, presumably reflecting a multiannual synthesis of moisture variability and changing hydrology. Synchronous long-term peat soil tree-growth variations observed over large parts of the Baltics point to a possible regional hydrological forcing. Our results may therefore improve hydrological reconstructions using living and subfossil peat-soil trees, and could be of prime importance given the major influence peatland water-table fluctuations have on a range of environmental processes.

Conclusion Results reveal that peat-soil pines are unsuitable for high-frequency climate reconstruction, but demonstrate their potential for the reconstruction of multi-annual to decadal hydrological fluctuations. Mineral-soil pines, by contrast, should be used for temperature reconstructions.

\footnotetext{
R. Šimanauskienè

Department of Geography and Land Management, Faculty of Natural Sciences, Vilnius University, M. K. Čiurlionio g. 21/ 27, LT-03101 Vilnius, Lithuania

M. Stoffel

Climatic Change and Climate Impacts, Institute for Environmental Sciences, University of Geneva, route de Drize 7, CH-1227 Carouge-Geneva, Switzerland

M. Stoffel

Department of Earth and Environmental Sciences, University of Geneva, Rue des Maraîchers 13, CH-1205 Geneva, Switzerland
} 
Keywords Dendrochronology · Meteorological data · Hydrology $\cdot$ Climate change $\cdot$ Regional climate

\section{Introduction}

Scots pine (Pinus sylvestris L.) has an extensive geographical distribution across Eurasia due to its ability to establish and survive in a wide range of environments (e.g., Carlisle and Brown 1968; Poyatos et al. 2007; Krakau et al. 2013). Findings from subfossil tree remains show that pines repeatedly have established on peat soils in Eurasian over the present interglacial period called the Holocene, i.e., the past 11,700 years (Gunnarson 1999; Pukienè 2001; Eckstein et al. 2009; Edvardsson et al. 2012). By contrast, studies from living trees point to an ongoing colonization, likely related to climatic and landuse changes (Linderholm and Leine 2004; Edvardsson et al. 2015). Due to the absence of reliable, highresolution proxies for the reconstruction of hydrology and precipitation covering the Holocene, increased interest has recently been addressed to the study of moisturesensitive subfossil peat-soil pine trees (Eckstein et al. 2009; Edvardsson et al. 2012). Several authors have presented hydrology as an important factor limiting growth of trees on peat soils (Boggie 1972; Edvardsson et al. 2012), but the exact interpretation of tree-ring data is not necessarily straightforward in these environments. At the same time, however, the role of hydrological variability of peatlands in relation to precipitation and temperature is essential for any prediction of the vulnerability, future vegetation dynamics and carbon storage capacity of northern peat soils to changing climatic conditions (Waddington et al. 2014), especially as peat soils represent substantial terrestrial carbon reservoirs of the boreal and subarctic regions (e.g., MacDonald et al. 2006; BACC 2008). Increased knowledge of factors controlling tree growth on peat soils is therefore needed to improve our understanding of peatland development, long-term climate change and moisture variability over the Holocene. It may also enable more robust predictions for future climate dynamics. Yet, despite the global importance of peatlands and the possible link between tree growth on peat soils and hydrology, few dendrochronological and dendroclimatological studies have been performed using living peat-soil trees. In Sweden, peat-soil trees have been studied by Linderholm (1999; 2001), in Finland by Hökkä et al. (2012), and in the Baltic region by Cedro and Lamentowicz (2011), Dauškane et al.
(2011) and Smiljanić et al. (2014). Furthermore, attempts to make large-scale comparisons of climate response of trees growing on peat and mineral soils are even scarcer (Linderholm et al. 2002; Cedro and Lamentowicz 2011).

The combination of humid conditions, with effective precipitation ranging from 20 to $45 \%$ (Gailiušis et al. 2001; Galvonaite et al. 2007), and the existence of appropriate landscape relief formed during the last deglaciation, have generated favourable conditions for peatland development in Lithuania (Kabailienè 2006). At present, more than $25 \%$ of Lithuania is covered by wetlands of which $7.8 \%$ has developed into peat bogs (Povilaitis et al. 2011). A recent study by Edvardsson et al. (2015) shows that pine trees are currently establishing in various peatlands in Lithuania, sometimes even at accelerating rates for the recent past. Due to the frequent presence of tree-covered peatlands, Lithuania has been considered to be a relevant area for a regional comparative study of tree growth on peat soils vs. mineral soils. In the past, hydrological processes have been studied in Lithuanian peatland ecosystems (Gaigalas et al. 2008; Linkevičienè et al. 2008; Taminskas et al. 2008; Mažeika et al. 2009), whereas analyses on peat-soil trees mainly focused on subfossil material (Pikšryte 1996; Pukienė 2001; Karpavičius 2005) or on the impacts of ecological changes (Vitas and Erlickytè 2007; Edvardsson et al. 2015).

In this study, we therefore aim at (i) comparing growth patterns of pine trees growing in peat soils and on adjacent, yet well-drained mineral soils in three different regions of Lithuania. Based on extensive dendrochronological analyses of 228 trees, we (ii) identify high- to lowfrequency wavelengths embedded in annually resolved ring-width series; (iii) use response function and pointer year analyses to investigate growth responses in pine trees to instrumental temperature and precipitation records at the inter-annual scale; (iv) compare smoothed and annual ring-width chronologies from all sites with monthly, annual, and smoothed mean temperature and precipitation data; and (v) discuss the interactions between hydrology, tree growth and climate.

\section{Methods}

Selection of study sites

Three pine-covered raised bogs called Aukštumala (S1), Kerèplis (S2), and Rèkyva (S3) were selected for tree- 
ring analyses (Fig. 1; Edvardsson et al. 2015). Sampling was limited to areas without visible scars so as to minimize the impact from anthropogenic activities such as ditching or peat mining. Pine stands growing on mineral soils in the surroundings of or, if possible, adjacent to bogs were sampled as well.

The Aukštumala raised bog is situated in southwestern Lithuania $\left(55^{\circ} 23^{\prime} \mathrm{N}, 21^{\circ} 22^{\prime} \mathrm{E}, 3018\right.$ ha, $1 \mathrm{~m}$ a.s.1.). The central and western parts of the bog remain preserved from anthropogenic activities and have therefore been selected for tree sampling. The area is characterised by scattered groups of trees, often separated by hundreds of meters of open surface. The mineral-soil stand is located $1 \mathrm{~km}$ to the east of the bog. At Kereplis raised bog $\left(54^{\circ} 27^{\prime}\right.$ $\mathrm{N}, 24^{\circ} 32^{\prime} \mathrm{E}, 144$ ha, $140 \mathrm{~m}$ a.s.1.), the sampled area in the northwestern part of the bog is characterized by relatively dense tree coverage. Mineral-soil trees were sampled on adjacent slopes where the underground consists of sandy glacio-fluvial sediments.
The Rèkyva peatland complex $\left(55^{\circ} 51^{\prime} \mathrm{N}, 23^{\circ} 15^{\prime} \mathrm{E}\right.$, $2608 \mathrm{ha}, 130 \mathrm{~m}$ a.s.1.) is composed of six raised bogs. The selected peat bog, the only one exempt from exploitation, is sparsely covered with different generations of pine trees. Trees growing on mineral soil were sampled on sandy slopes $10 \mathrm{~km}$ to the southwest of the bog.

\section{Chronology development and statistics}

During fieldwork campaigns in May and September 2013, cores from 228 pine trees were collected using a Pressler increment borer. In total, 171 pines (56 at Aukštumala, 63 at Kerèplis and 52 at Rèkyva) growing on peat soils exceeding $3 \mathrm{~m}$ in thickness were sampled. In addition, in order to isolate tree-growth variations specifically related to bog hydrology, we cored 57 pine trees $(22,20$, and 15 in the surroundings of S1, S2 and $\mathrm{S} 3$, respectively) growing on well-drained mineral soils.
Fig. 1 The black dots show the location of the study sites: (S1) Aukštumala, (S2) Kerèplis and (S3) Rèkyva, all located in Lithuania (inset). The white dots show the meteorological stations (I) Vilnius, (II) Šiauliai and (III) Šilutè. Large peatland complexes are shown in grey. Overviews of the three study areas are shown in (a-c). The borders of peatlands are shown in white and the main study areas are indicated in black. Orthophotos were obtained from the National Land Service under the Ministry of Agriculture, Lithuania

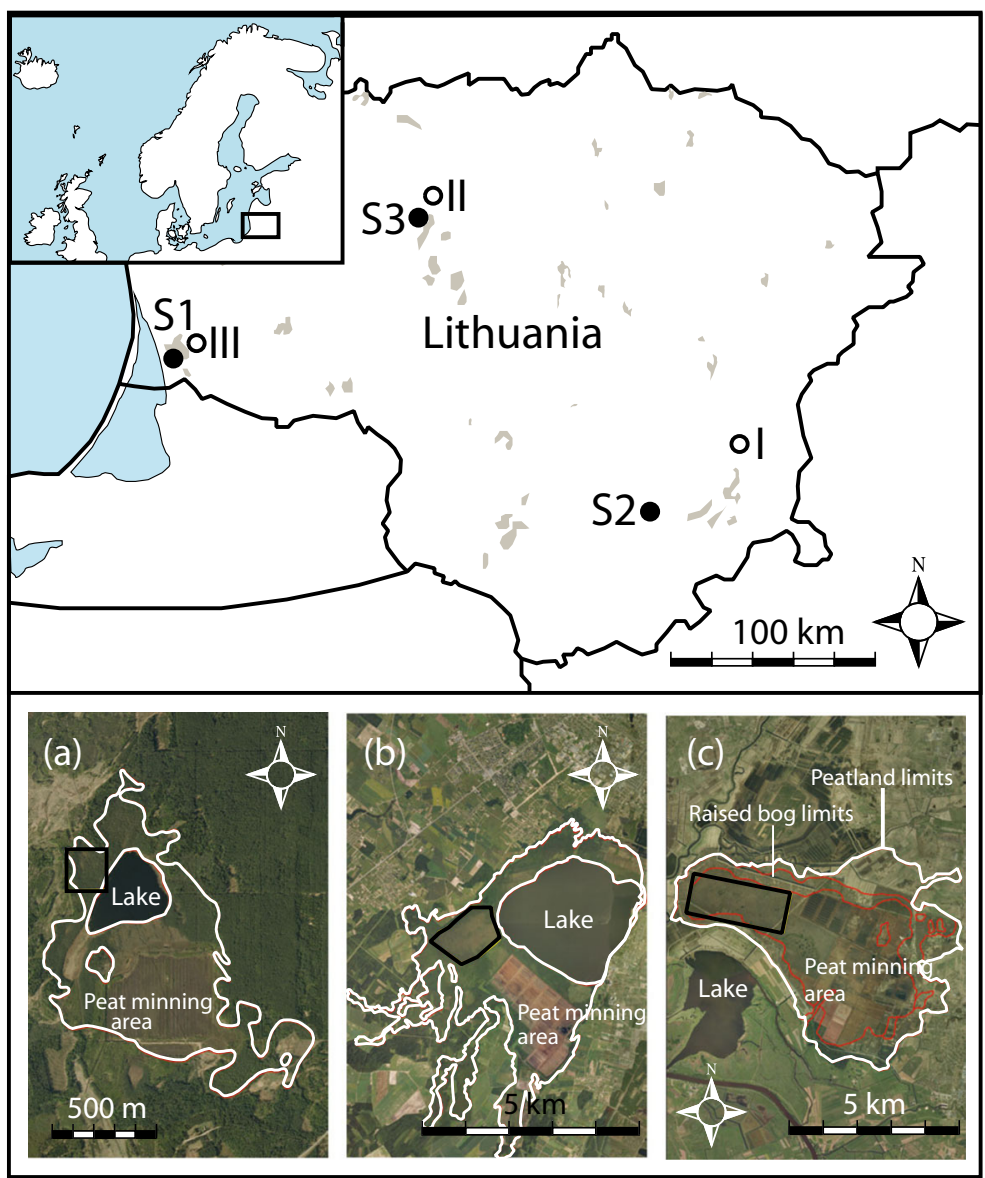


Increment samples were analysed and data processed following standard dendrochronological procedures (Bräker 2002). Ring widths (RW) were measured to the nearest $0.01 \mathrm{~mm}$ using a digital LINTAB positioning table connected to a Leica stereomicroscope and TSAPWin Scientific software (Rinn 2003). Prior to standardization, all RW series were cross-dated for missing rings and dating errors using COFECHA (Cook and Holmes 1984). To minimise the influence of non-climatic variations and trends, related to e.g., tree age and geometry, the RW series were standardized and transformed into dimensionless indices (Fritts 1976; Cook and Kairiukstis 1990) using either ARSTAN_41d (Cook and Krusic 2006) or dedicated packages in $\mathrm{R}$ ( $\mathrm{R}$ Development Core Team 2012). As non-significant synchronism was detected between the peat soil and mineral soil pines, and to preserve potential low-frequency variations in the tree growth, a flexible Friedman's variable span smoother (Friedman 1984) was used for standardization. We also analysed Expressed Population Signal (EPS) statistics which quantifies the strength of the common climate signal in the tree-ring proxies (Wigley et al. 1984) and used the commonly applied quality threshold of 0.85 to determine the reliability of our chronologies.

Because tree-growth persistence cannot be readily discriminated from climatic persistence (e.g., Cook 1985), residual chronologies corrected for autocorrelation were developed using autoregressive modelling (ARIMA, 1,1,1) and thereafter used for comparison with meteorological data. Pointer years were then calculated on the basis of the distribution of RW indices. RW indices within the fourth (PY-IV) and the first (PY-I) quartile were associated to strong and depressed growth, respectively.

\section{Climate growth relationships}

On the inter-annual scale, climate-growth relationships have been tested with response function analyses, a form of principal component regression designed to account for collinearity of monthly climate predictors (Fritts 1976). We have used the "DENDRO" script (Mérian 2012) developed under the $\mathrm{R}$ software (Development Core Team 2012) for this purpose. In detail, bootstrapped response coefficients have been calculated over the
1951-2012 period using residual RW chronologies as dependent variables (Guiot 1991) and 24 successive climatic regressors from the closest meteorological station from each site. These were represented by 12 temperature and precipitation values each organized from September of the previous growth season (n-1) to August of the year during which the annual growth ring was formed (n). Meteorological data, namely monthly mean, maximum and minimum air temperature $\left({ }^{\circ} \mathrm{C}\right)$ and total monthly precipitation $(\mathrm{mm})$ from the Šilute, Šiauliai and Vilnius meteorological stations (Fig. 1), located at the vicinity of the sample sites, have been used as climatic regressors. Missing monthly values in meteorological series were filled with the ratio method and by using supplementary data from other nearby meteorological stations.

In a second step, based on similar meteorological series, we determined climatic factors associated with extreme years as identified during the pointer year analysis. Mean monthly climatic anomalies during years characterized by strong and depressed growths (i.e., PY-I and PY-IV, respectively) were compared and the significance in mean differences evaluated based on a Student's $t$-test.

At the decadal scale, monthly air temperature (1852-2013) and precipitation (1887-2013) timeseries from Vilnius meteorological station have been used to assess climate-growth relationships. The data series from Vilnius were considered to properly reflect the meteorological conditions in Lithuania as (i) Pearson's correlation analysis between monthly temperature in Šiauliai and Šilutè and the meteorological series of Vilnius exceed 0.9 for the interval for which all the series overlap (1951-2012); and as (ii) monthly precipitation in Šiauliai and Šilutè are significantly correlated $(p<0.05)$ with monthly precipitations in Vilnius except for May. For further statistical and visual comparisons, smoothed chronologies and meteorological data series were developed using either an 11-year moving average or flexible spline functions. Finally, in order to investigate the possible delay in response of tree growth to hydrological fluctuations, lagged correlations were computed between tree-ring chronologies and yearly rainfall totals in Vilnius. For this purpose, the meteorological series was shifted back in time with a timeoffset varying from 1 to 10 years. 


\section{Results}

Ring-width chronologies

Six RW chronologies were developed in this study (Fig. 2, Table 1), three from trees collected at the Aukštumala (S1PS), Keréplis (S2PS) and Rèkyva (S3PS) peat soils, and three from trees sampled on mineral soils in the periphery of each of these bogs (S1MS, S2MS, and S3MS). The chronologies are between 76 and 212 years in length, and were developed from $66 \%$ of the peat-soil trees and $96 \%$ of the mineral soil trees collected. The annual tree growth was stronger at the mineral-soil sites as these trees produced two to four times wider annual growth rings, on average, than the peat-soil trees (Table 1). Interestingly, no significant correlations were observed between chronologies from the same geographic region but from trees growing on different soil types. Meanwhile, correlation coefficients
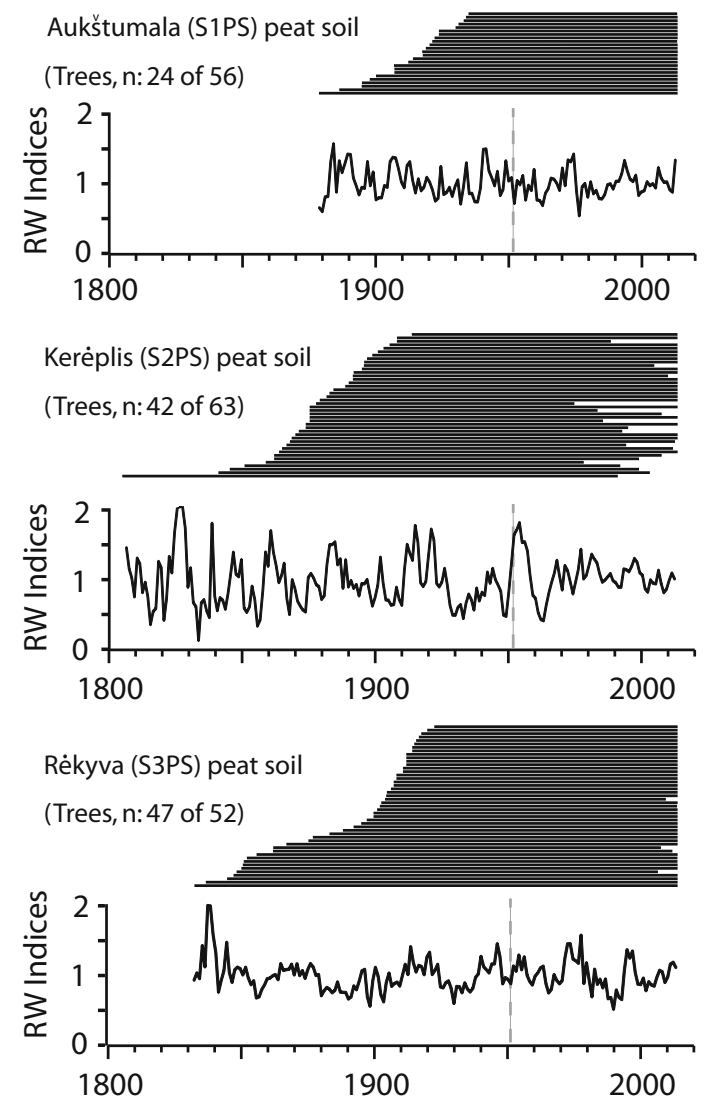

Fig 2 The six ring-width $(R W)$ chronologies developed from the three study areas: Peat soil RW chronologies are shown on the left panel, chronologies developed from trees growing on mineral soils are shown on the right panel. The horizontal black lines represent computed between RW chronologies from mineral soil trees range from 0.40 to $0.62(p<0.05)$, while lower, yet significant correlations $(0.26-0.35, p<0.05)$ were obtained for the peat-soil tree RW chronologies (Table 2). After smoothing, weaker (yet not significant) correlations were computed between the mineral-soil chronologies $(0.01-0.20)$, whereas increased values $(0.30-0.69)$ were observed between the RW chronologies from peat-soil trees.

Years characterized by depressed growth (PY-1) were observed synchronously (Fig. 3) in the three peat-soil tree chronologies in 1979 and in two out of three chronologies in 1956, 1960, 1965, 1966, 1974, 1982, 1984, 1986, 2000, 2002, 2008, and 2009. Conversely, two positive extreme years (PY-4, 1957, 1994) were detected in all the peat-soil tree RW chronologies and 9 in at least two (1953, 1955, 1969, 1972, 1973, 1977, 1978, 1980, and 1995). At the mineral sites, depressed growth (PY-1) occurred synchronously at all the sites in 1976,

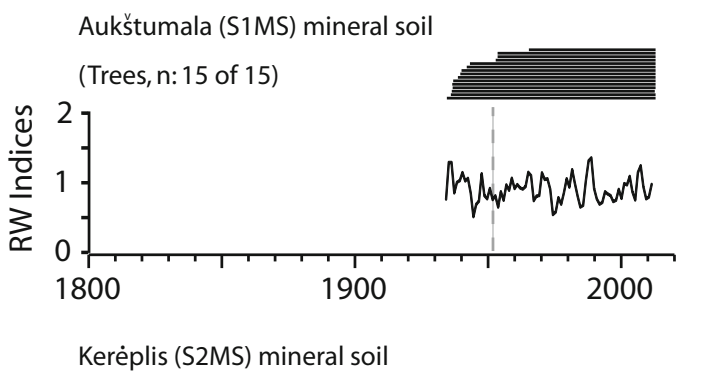

(Trees, n: 20 of 22)

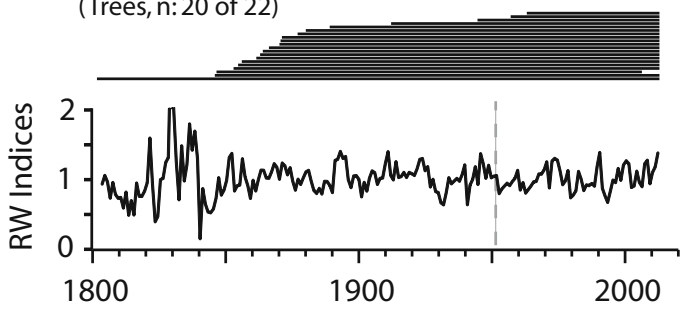

Rèkyva (S3MS) mineral soil

(Trees, n: 20 of 20)

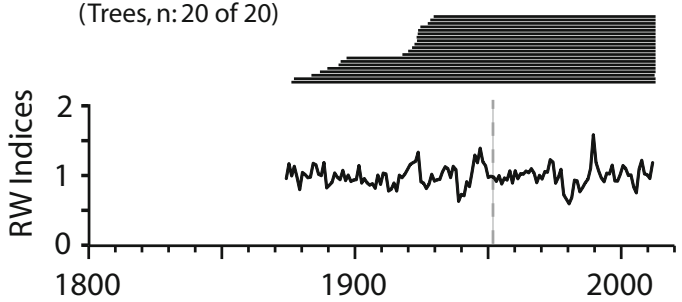

individual trees. Black curves correspond to standardized RW (dimensionless indices) chronologies. The dashed lines show the onset of the period used for dendroclimatological analyses 
Table 1 General information about the RW chronologies

\begin{tabular}{|c|c|c|c|c|c|c|}
\hline & $\begin{array}{l}\text { Aukštumala } \\
\text { (S1B / bog) }\end{array}$ & $\begin{array}{l}\text { Kerèplis } \\
\text { (S2B / bog) }\end{array}$ & $\begin{array}{l}\text { Rėkyva } \\
\text { (S3B / bog) }\end{array}$ & $\begin{array}{l}\text { Aukštumala } \\
\text { (S1S / soil) }\end{array}$ & $\begin{array}{l}\text { Kerèplis } \\
\text { (S2S / soil) }\end{array}$ & $\begin{array}{l}\text { Rèkyva } \\
\text { (S3S / soil) }\end{array}$ \\
\hline Trees (n) / length (years) & $24 / 127$ & 42 / 207 & $47 / 180$ & $15 / 76$ & $20 / 212$ & $20 / 138$ \\
\hline Total period & 1887-2013 & 1807-2013 & $1834-2013$ & 1937-2012 & $1801-2012$ & 1875-2012 \\
\hline $\mathrm{EPS} \geq 0.85$ & 1940-2013 & $1865-2013$ & 1905-2013 & 1960-2012 & $1890-2012$ & 1930-2012 \\
\hline Series inter-correlation & 0.443 & 0.586 & 0.516 & 0.509 & 0.467 & 0.467 \\
\hline Average RW (mm) & 0.79 & 0.54 & 0.48 & 2.70 & 1.05 & 2.17 \\
\hline
\end{tabular}

1979,1991 , and 2009, and in two of the three stands in 1954, 1956, 1960, 1962, 1969, 1980, 1985, 1992, 1993, 2005, and 2006. Strong growth (PY-4) was observed in all stands in 1989, 1990, 2000, 2007, and 2008, and in two of the three stands in 1959, 1961, 1970, 1972, 1983, 1995, 1997, 2004, and 2012.

Dendroclimatological analyses at the inter-annual scale

In the case of the peat-soil trees, the response function analyses yield differing results between the sites (Fig. 4). At S1PS, responses were dominated by precipitation in November (n-1) and August (n). Positive, albeit not statistically significant, responses of the radial growth to temperatures prior the onset of the vegetative period (Jan-Apr t) were also observed at S1PS. Response function profiles evidence the absence of climatic factors controlling significantly tree-ring width at S2PS and S3PS. Sitedependent responses to temperature were observed during extreme years. No statistically significant $(p<0.05)$ differences were found in any given month for years with extreme growth deviations at S1PS (Fig. 5). At S2PS, November and December temperatures differ significantly from the mean during

Table 2 Correlation matrixes between RW chronologies from all study sites with correlation values for the smoothed chronologies given in brackets. Statistically significant correlation coefficients extremely positive and negative years. At S3PS, higher temperatures in May characterize negative extreme years. No significant differences were observed for precipitation (not presented here). A negative, yet statistically significant correlation was observed with the length of the growing period at Kereplis $(-0.30, p<0.05)$. No significant $r$-values $(0.21$ and -0.02$)$ were obtained in Aukštumala and Rèkyva.

Both the response function (Fig. 4) and pointer year analyses (Fig. 5) revealed a positive influence of pregrowth season temperatures (Feb, Mar) on pine growth at the mineral-soil sites. Significantly different temperatures $(p<0.05)$ between PY-I and PY-IV were recorded for (i) March (t) at all three sites, (ii) February (t) at S1MS and S3MS, and (iii) January (t) at S3MS. Statistically significant $(p<0.05)$ positive correlations (r) were observed between tree growth and the length of the vegetative period ( $\mathrm{S} 1 \mathrm{MS}=0.43, \mathrm{~S} 2 \mathrm{MS}=0.39$ and $\mathrm{S} 3 \mathrm{MS}=0.53$ ). Strong growth years (e.g., 1990, 2000, 2007, and 2008) were also frequently associated with long growing seasons. By way of example, meteorological data from Siauliai show that 1990 experienced the longest recorded growing season since 1937 with temperatures above $5{ }^{\circ} \mathrm{C}$ for 246 consecutive days. $(p<0.05)$ for the annually resolved chronologies are highlighted in bold. Significance levels have not been calculated for the smoothed chronologies

\begin{tabular}{|c|c|c|c|c|c|c|}
\hline & Aukštumala-bog & Kerèplis-bog & Rèkyva-bog & Aukštumala-soil & Kerèplis-soil & Rèkyva-soil \\
\hline \multicolumn{7}{|l|}{ Aukštumala-bog } \\
\hline Kerèplis-bog & $0.18(0.45)$ & & & & & \\
\hline Rèkyva-bog & $\mathbf{0 . 2 9}(0.69)$ & $\mathbf{0 . 3 5}(0.30)$ & & & & \\
\hline Aukštumala-soil & $0.25(-0.56)$ & $-0.01(-0.61)$ & $0.17(-0.52)$ & & & \\
\hline Kerèplis-soil & $0.14(0.62)$ & $0.08(0.16)$ & $0.21(0.37)$ & $\mathbf{0 . 4 0}(0.20)$ & & \\
\hline Rèkyva-soil & $\mathbf{0 . 2 6}(0.47)$ & $0.01(-0.02)$ & $0.22(0.11)$ & $\mathbf{0 . 5 9}(0.01)$ & $\mathbf{0 . 6 2}(0.13)$ & \\
\hline
\end{tabular}


Fig. 3 Number of visible pointer years showing strong (fourth quartile) and depressed tree growth (first quartile) in the RW chronologies from (a) peat soils and (b) mineral soils

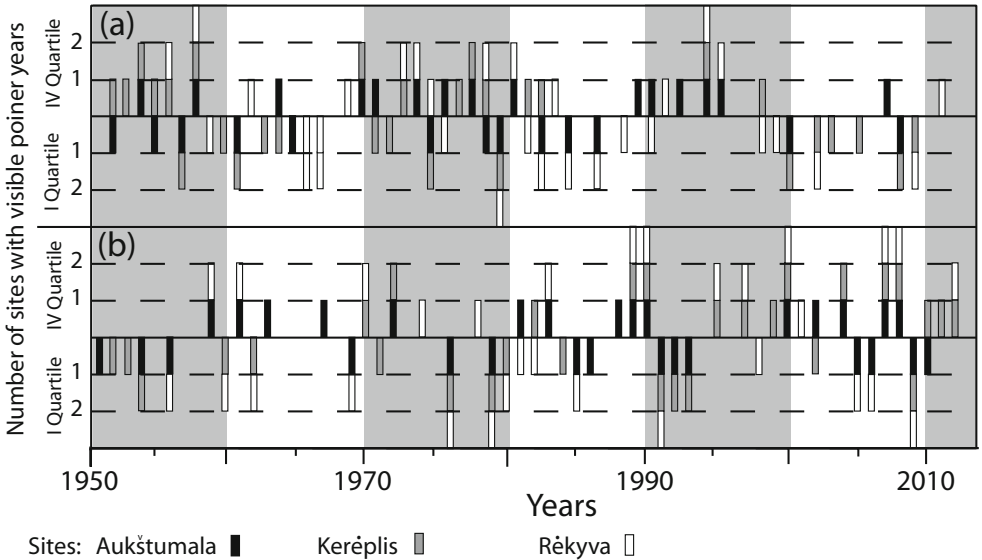

In addition, the influence of drought was observed during extreme negative years. By way of example, the years 1976 and 1979 show depressed tree growth at all mineral-soil sites (PY-I), which can be associated with unusually cold and dry conditions at the study sites. The year 1976 was, for instance, the driest since 1950 in the Vilnius and Šilutè meteorological records.

Dendroclimatological analyses at the decadal scale

After smoothing, correlations between RW chronologies developed from peat-soil trees increased (Table 2; Fig. 6). Smoothed chronologies showed a common decadal variability in radial tree growth with clear positive trends during the 1910s and the 1970s and synchronous depressions during the late 1920s, 1930s, and the 1960s (Fig. 6a-d). Decadal RW fluctuations properly coincide with rainfall totals at Vilnius (Fig. 6h). Conversely, no common decadal variability was observed in the chronologies from the mineral-soil trees: r-coefficients between mineral-soil chronologies systematically decline in this approach (Table 2) and the visual comparison exhibit no clear synchronicities between the smoothed chronologies (Fig. 6e).

Lagged correlation analyses indicate delayed peatsoil RW responses to annual precipitation measured in Vilnius. For the smoothed series, the correlation coefficient peaked when the time-offset was 5 years in Rèkyva $(r=-0.43)$ and 7 years both in Aukštumala $(r=-0.35)$ and Keréplis $(r=-0.52)$. Meanwhile, using series with annual resolution, the correlation peaked

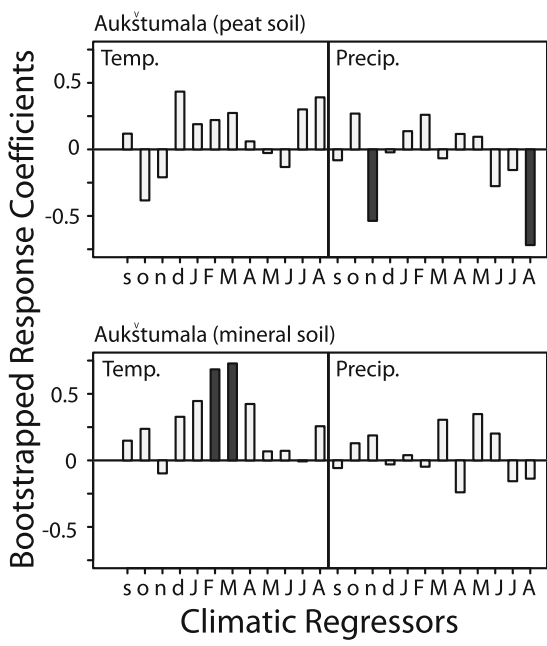

Fig. 4 Response function analyses for the six tree-ring chronologies with temperature (Temp.) and precipitation (Precip.) data from the nearest meteorological stations. Months for each regressor are
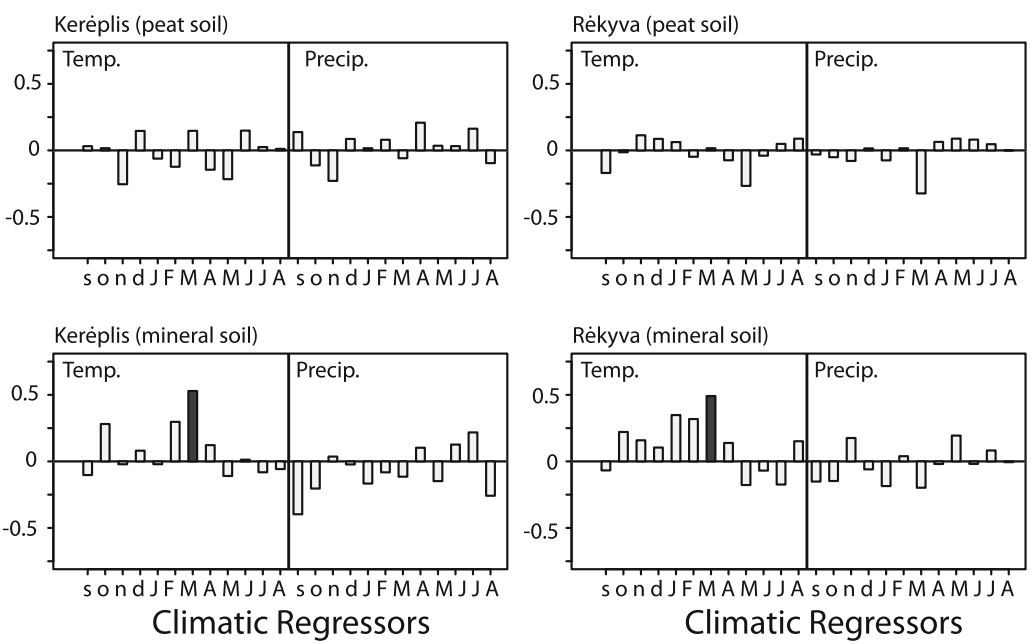

indicated below, with months of the considered year (n) in capital letters and those of the previous year (n-1) in small letters. Significant response coefficients are highlighted with shaded bars 

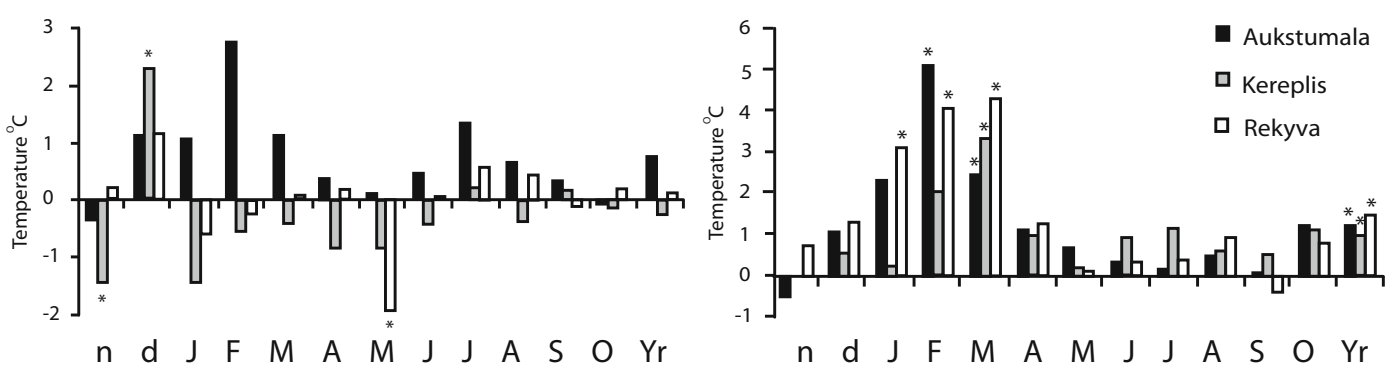

Fig. 5 Air temperature difference between positive (IV quartile) and negative (I quartile) extreme years. Peat soil trees are shown to the left and mineral soil trees to the right. Statistically significant differences $(p<0.05)$ according to $t$-test are shown with stars

after 2 years in Aukštumala $(r=-0.20), 3$ years in Keréplis $(-0.23)$, and 4 years in Rékyva $(r=-0.31)$. No similar lag response was observed between longterm temperature variations and peat-soil tree growth for any particular lag, or between long-term precipitation and tree growth records from the mineral-soil trees.

\section{Discussion}

Weak inter-annual climatic signal at bog sites

The significant correlations observed between the mineral-soil tree chronologies (Table 2) demonstrate that meteorological conditions prevailing at the regional level control RW formation of trees growing on mineral soils in Lithuania. Both response function and extreme year analyses show that warm winter and early spring temperatures are the primary factors favouring annual tree growth at mineral-soil sites. Remarkable differences in monthly mean temperatures were also detected between years associated with strong (PY-IV) versus depressed (PY-I) tree growth at the mineral-soil sites (Fig. 5). Largest variations were observed for February temperatures in the Aukštumala area, and show that pregrowth season conditions can vary significantly, especially in the coastal regions. Similar observations on tree growth of Baltic pines and winter-spring temperatures have been reported in Lithuania (Vitas 2004), Latvia (Elferts 2007), Estonia (Hordo et al. 2009; Pärn 2009) and in the Polish lowlands (Cedro 2001; Cedro and Lamentowicz 2011). Favourable conditions prevailing in winter and early spring have been described to induce increased cambium activity during the subsequent growth season and to produce larger annual tree rings (Cedro and Lamentowicz 2011). Higher air temperature may also mean less winter damage to roots, less growth limitations (Dauškane et al. 2011) and effective photosynthesis on warm winter days, provided that conifer needles are not frozen (Havranek and Tranquillini 1995).

Conversely, weak correlation coefficients between the peat-soil tree chronologies point to the presence of a complex signal, likely related to local bog hydrology. At the site scale, the lack of significant correlation between chronologies from different soil types corroborates this hypothesis. The peat-soil trees sampled at Kereplis bog (S2PS) and the adjacent mineral soils (S2MS) are, for instance, only separated by 60 to $400 \mathrm{~m}$. Despite this vicinity, a weak, insignificant correlation $(r=0.08)$ is computed between the two respective chronologies. Additionally, the low productivity and the high rates of rejection of peat-soil trees related to missing and wedging growth rings, confirm that harsh growth conditions - e.g., high water table, the substantial acidity of the water, and the deficiency of nutrients significantly impact tree growth on peat soils (Freléchoux et al. 2000; Vitas and Erlickyte 2007). Given this impact of peatland hydrology on RW a clear response of tree-ring growth to prevailing climatic conditions cannot be found. Interestingly, climatic anomalies during winter sometimes result in opposite extreme tree-growth responses on peat soil and mineral soil environments. By way of example, the strongest and weakest tree growth over the period 1937-2012 is observed in 1990 at the mineral soil (S3MS) and peat-soil sites (S3PS) at Rékyva, respectively. This opposite re-

Fig. 6 a-d Peat-soil tree RW chronologies, e mineral-soil tree RW chronologies, $\mathbf{f}$ precipitation and temperature records, $\mathbf{g}$ average annual temperature and $\mathbf{h}$ average annual precipitation. Black curves $(\mathbf{a}-\mathbf{c}, \mathbf{g}$ and $\mathbf{h})$ are annual resolution whereas the red curves are smoothed using a 30-year flexible spline. The data series in $\mathbf{d}$ to $\mathbf{f}$ are smoothed using a 11-year moving average. The blue bars emphasize moist periods associated with positive precipitation anomalies, grey lines represent average values and the letter $C$ is for callus tissue formed after a fire. All meteorological data is from Vilnius weather station 


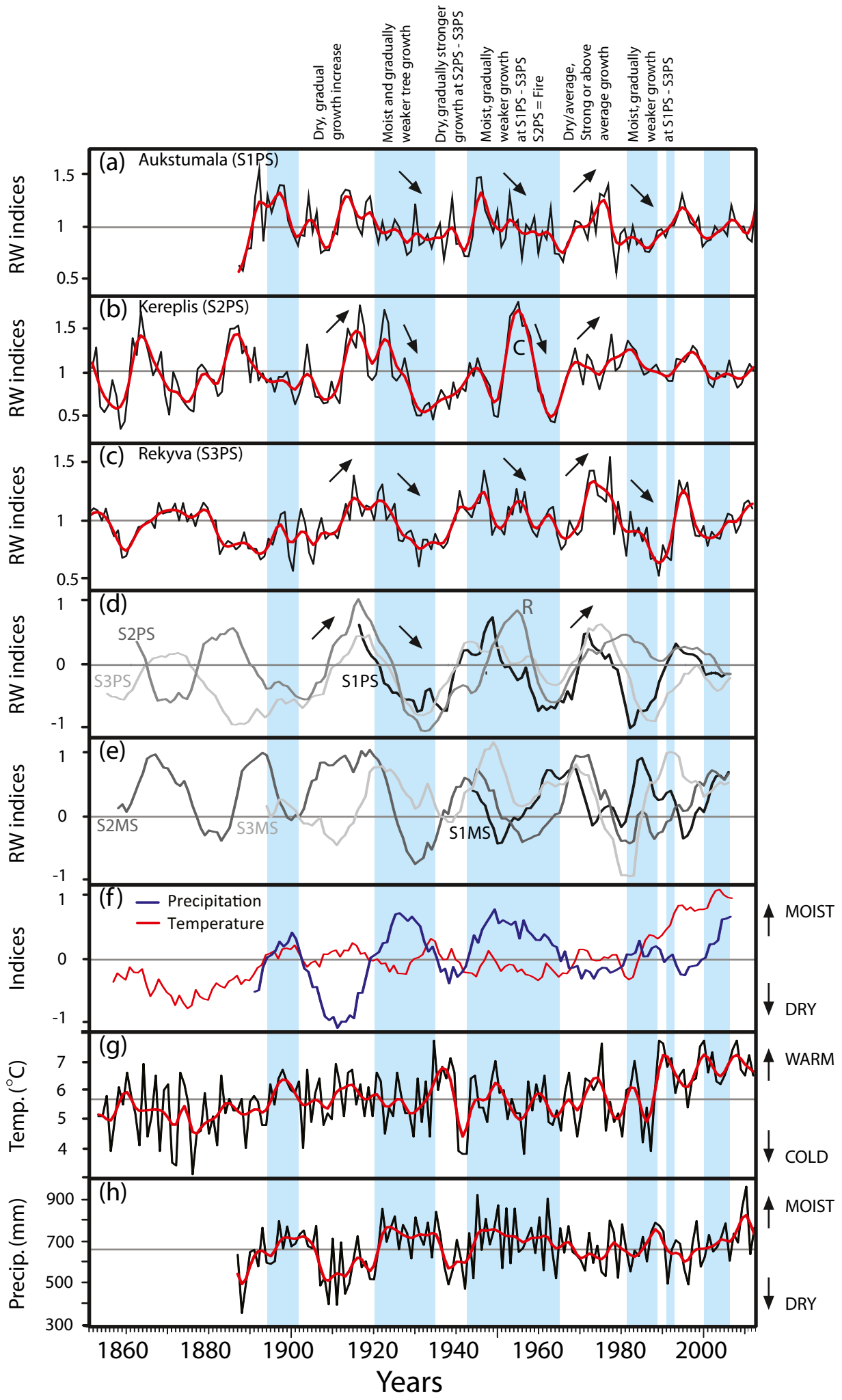


sponse is probably generated by positive precipitation anomalies, recorded from January to March 1990, and related to the prevalence of warm and moist air. This constellation may have generated favourable growth conditions at the mineral-soil sites, but wetter peat-soil conditions which in turn limit tree growth in peatlands. Extremely narrow growth rings in 1990 have also been observed in Latvian peatlands (Dauškane et al. 2011). Response function profiles evidence no predominant climatic factors controlling inter-annual RW variability but suggest micro-climatic influences on tree growth.

Regional decadal trends

At the decadal timescale, correlation analyses between smoothed chronologies indicate a regional and multiannual moisture signal in the peat-soil tree chronologies, which is probably related to regional precipitation fluctuations. A possible explanation for the weak inter-annual, but improved multi-annual responses to climate may be that once a peat soil has been saturated with water, temperature or precipitation changes over single months may not cause any notable hydrological variations affecting the growth conditions for the trees. In fact, various authors (e.g., Ingram and Gore 1983; Almendinger et al. 1986; Charman et al. 2004) indeed suggested that hydrological responses in peatlands tend to be slow and that they depend on persistent climate rather than on short-term variations. In that sense, the depressed tree growth observed in all peat bogs during the 1920s, 1930s, and 1960s coincide with period for which above-average precipitation has been recorded (Fig. 6). The gradual decrease in tree growth on peat soils recorded during the 1920s and early 1930s may thus be associated with the long-term, above average (+ $12 \%$ with ref. to the $1887-2013$ period) precipitation recorded at Vilnius meteorological station for the period 1922-1931. Similar depressed growth has been observed in Poland at the Słowinskie Błoto peat bog (Cedro and Lamentowicz 2011) and in Latvian bogs during this same period, especially during the years 1926, 1928, and 1931 (Dauškane et al. 2011). The positive precipitation anomaly observed during the mid-1940s and 1950s also coincides with a gradual growth decrease detected in the Rékyva and Aukštumala chronologies from peat-soil trees. A similar growth behaviour is observed in Poland (Cedro and Lamentowicz 2011), whereas the strong growth increase during the 1950 s at Kerèplis bog was mainly caused by wide growth rings with callus tissues formed after a fire. Conversely, long-term anomalies associated with less than average precipitation generated lower water tables and drier peat-soil conditions. For example, drier conditions (with $-18 \%$ of the normal precipitation total) prevailed between 1907 and 1916 and indeed proved to be favourable in terms of RW formation in the peat-soil trees. The relatively dry conditions during the 1970 s may also explain the strong growth observed at all peat bogs during this period. Increased annual tree growth since 1971 is also detected at the Männikjärve bog (Estonia; Smiljanić et al. 2014) and associated with low water tables (Charman et al. 2004).

The decadal signal described herein may be attributed to delays or multi-annual hydrological responses to regional climatic fluctuations affecting tree growth on peat soils. This hypothesis is consistent with previous studies (Linderholm et al. 2002; Edvardsson et al. 2014), suggesting that gradual changes in climate may not necessarily affect water tables of peatlands instantly and therefore may not affect tree growth either. In this study, possible multi-annual lags of up to 5 or 7 years have been detected between hydrological parameters and RW in trees. This is compatible with results discussed by Edvardsson et al. (2014), comparing treegrowth responses of subfossil trees to atmospheric moisture variations detected in stable isotope records. The authors of that study report a 1 year integrated climatic response in peat-soil trees. Similar delays in hydrological responses, in the order of a few years and several decades, have been presented by Kilian et al. (1995). Slow hydrological responses may partly be related to precipitation falling as snow and water transport in soils towards the peat bogs, but can also be attributed to the process by which water is replacing air in the relatively large pore spaces of the unsaturated zone of peat (Ingram and Gore 1983; Almendinger et al. 1986). Peat soils are also compressible and changes in water content may result in volumetric fluctuations, which are detectable as variations in surface elevation, which can in turn vary depending on the amount of water that is stored in the bogs (Almendinger et al. 1986; Price and Schlotzhauer 1999).

\section{Conclusions}

This study compares growth variability of pine trees growing on peat soils and mineral soils in three separate 
regions of Lithuania. Growth and climate response patterns differ between trees on peat soils and the neighbouring mineral soils. The annual to inter-annual climatic information in the chronologies from peat-soil trees is much weaker than for pines growing on nearby mineral soils. Results also demonstrate that RW of trees on mineral soils record the positive effects of warm winters and early springs and thus confirm results reported from areas adjacent to the southern Baltic coast and the Polish lowlands. At the same time, however, the annual-growth patterns of the pine trees growing on peat soils are more complex to interpret. At the inter-annual scale, these patterns are loosely associated with the weather conditions due to the hydrology of the bogs, which impact tree growth by generating harsh growth conditions. At the decadal scale, the synchronous growth variations observed in the smoothed chronologies and over large parts of the Baltic area reveal a largescale climatic control. The complex signal observed in peat-soil trees is thus interpreted as a combination of the direct, primary effect of growth-year climate superimposed to a multi-year integrated response to water-table fluctuations controlled by regional climate. With all factors combined, living and subfossil peat-soil pines in the Baltic area tend to have a limited potential for the reconstruction of inter-annual hydrological variations, but represent valuable proxies for annual to decadal reconstructions, whereas mineral-soil pines preferably reflect the effect of temperatures.

Acknowledgments This study has been funded by the Lithuanian-Swiss cooperation program to reduce economic and social disparities within the enlarged European Union under the name CLIMPEAT (Climate change in peatlands: Holocene record, recent trends and related impacts on biodiversity and sequestered carbon) project agreement No CH-3-ŠMM-01/05. Kazimieras Dilys, Marija Tamkevičiute and Sigita Butkute are thanked for their help during the fieldworks and the anonymous referees for their suggestions for improvements.

\section{References}

Almendinger JC, Almendinger JE, Glaser PH (1986) Topographic fluctuations across a spring fen and raised bog in the Lost River Peatland, Northern Minnesota. J Ecol 74:393-401

BACC Author Team (2008) Assessment of climate change for the Baltic Sea basin. Springer, Berlin, p 474

Boggie R (1972) Effect of water-table height on root development of Pinus contorta on deep peat in Scotland. Oikos 23:304 312
Bräker OU (2002) Measuring and data processing in tree-ring research-a methodological introduction. Dendrochronologia 20:203-216

Carlisle A, Brown AHF (1968) Pinus sylvestris L. J Ecol 56:269-307

Cedro A (2001) Dependence of radial growth of Pinus sylvestris L. from Western Pomerania on the rainfall and temperature conditions. Geochronometria 20:69-74

Cedro A, Lamentowicz M (2011) Contrasting responses to environmental changes by pine (Pinus sylvestris L.) growing on peat and mineral soil: an example from a Polish Baltic bog. Dendrochronologia 29:211-217

Charman DJ, Brown AD, Hendon D, Karofeld D (2004) Testing the relationship between Holocene peatland palaeoclimate reconstructions and instrumental data at two European sites. Quat Sci Rev 23:137-143

Cook ER (1985) A time series analysis approach to tree-ring standardization. Dissertation, University of Arizona, Tucson

Cook ER, Holmes RL (1984) Program ARSTAN user manual: laboratory of tree ring research. University of Arizona, Tucson

Cook ER, Kairiukstis LA (1990) Methods of dendrochronology, applications in the environmental sciences. Kluwer Academic Publishers, International Institute for Applied Systems Analysis, London

Cook ER, Krusic PJ (2006) ARSTAN_41: a tree-ring standardization program based on detrending and autoregressive time series modeling, with interactive graphics. Tree-Ring Laboratory, Lamont Doherty Earth Observatory of Columbia University, New York

Dauškane I, Brūmelis G, Elferts D (2011) Effect of climate on extreme radial growth of Scots pine growing on bogs in Latvia. Estonian J Ecol 60:236-248

Development Core Team R (2012) R: A language and environment for statistical computing. R Foundation for Statistical Computing, Vienna

Eckstein J, Leuschner HH, Bauerochse A, Sass-Klaassen U (2009) Subfossil bog-pine horizons document climate and ecosystem changes during the Mid-Holocene. Dendrochronologia 27:129-146. doi:10.1016/j.dendro.2009.06.007

Edvardsson J, Linderson H, Rundgren M, Hammarlund D (2012) Holocene peatland development and hydrological variability inferred from bog-pine dendrochronology and peat stratigraphy - a case study from southern Sweden. J Quat Sci 27:553563

Edvardsson J, Edwards TWD, Linderson H, Hammarlund D (2014) Climate forcing of growth depression in subfossil South Swedish bog pines inferred from stable isotopes. Dendrochronologia 32:55-61

Edvardsson J, Šimanauskienė R, Taminskas J, Baužienė I, Stoffel M (2015) Increased tree establishment in Lithuanian peat bogs - Insights from field and remotely sensed approaches. Sci Total Environ 505:113-120. doi:10.1016/j.scitotenv. 2014.09.078

Elferts D (2007) Scots pine pointer-years in northwestern Latvia and their relationship with climatic factors. Acta Univ Latv 723:163-170

Freléchoux F, Buttler A, Schweingruber FH, Gobat JM (2000) Stand structure, invasion, and growth dynamics of bog pine (Pinus unicinata var. rotundata) in relation to peat cutting and drainage in the Jura Mountains, Switzerland. Can J For Res 30:1114-1124 
Friedman JH (1984) A variable span smoother, department of statistics technical report LCS 5. Stanford University, Stanford

Fritts HC (1976) Tree rings and climate. Academic, London

Gaigalas A, Vaikutienė G, Vainorius J, Kazlauskas M (2008) Development of Lake Rèkyva and its environment in Late Pleistocene and Holocene. Geologija 1:28-36

Gailiušis B, Jablonskis J, Kovalenkovienė M (2001) Lietuvos upès: hidrografija ir nuotékis [Lithuanian Rivers: Hydrography and Runoff]. Lithuanian Energy Institute, Kaunas, p 792

Galvonaitė A, Misiūnienė M, Valiukas D, Buitkuvienė MS (2007) Lietuvos klimatas [Lithuanian Climate]. Lithuanian Hydrometeorological Service, Vilnius, p 208

Guiot J (1991) The bootstrapped response function. Tree-Ring Res 51:39-41

Gunnarson BE (1999) A 200-year tree-ring chronology of pine from a raised bog in Sweden: implication for climate change? Geogr Ann A 81:421-430

Havranek WM, Tranquillini W (1995) Physiological processes during winter dormancy and their ecological significance. In: Smith WK, Hinckley TM (eds) Ecophysiology of coniferous forests. Academic, San Diego, pp 95-124

Hökkä H, Salminen H, Ahti E (2012) Effect of temperature and precipitation on the annual diameter growth of Scots pine on drained peatlands and adjacent mineral soil sites in Finland. Dendrochronologia 30:157-165

Hordo M, Metslaid S, Kiviste A (2009) Response of Scots pine (Pinus sylvestris L.) radial growth to climate factors in Estonia. Baltic For 15:195-205

Ingram HAP (1983) Hydrology. In: Gore AJP (ed) Mires, Swamp, Bog, Fen, and Moor, General Studies, Vol. 4A. Elsevier, Amsterdam, pp 67-158

Kabailienè M (2006) Gamtinès aplinkos raida Lietuvoje per 14000 metu [Development of Natural Environment in Lithuania During 14000 Years]. Vilnius University, Vilnius, p 471

Karpavičius J (2005) Compoling of long-term tree ring chronology of pine (Pinus sylvestris L.), Growing in aukštoji plynia peat bog during the subatlantic period. LUA Res Papers 68:12-19

Kilian MR, Van der Plicht J, Van Geel B (1995) Dating raised bogs. New aspects of AMS ${ }^{14} \mathrm{C}$ wiggle matching, a reservoir effect and climatic change. Quat Sci Rev 14:959-966

Krakau U-K, Liesebach M, Aronen T, Lelu-Walter M-A, Schneck V (2013) Scots pine (Pinus sylvestris L.). In: Pâques LE (ed) Forest tree breeding in Europe, vol 25. Managing forest ecosystems. Springer, Netherlands, pp 267-323

Linderholm HW (1999) Climatic and anthropogenic influences on radial growth of Scots pine at Hanvedsmossen, a raised peat bog, in south central Sweden. Geogr Ann A 81:75-86

Linderholm HW (2001) Climate influence on Scots pine growth on dry and wet soils in the central Scandinavian mountains, interpreted from tree-ring widths. Silva Fenn $35: 415-424$

Linderholm HW, Leine M (2004) Assessing twentieth century tree-cover changes on a southern Swedish peatland combining dendrochronolgical and remote sensing methods. Wetlands 24:357-363

Linderholm HW, Moberg A, Grudd H (2002) Peatland pines as climate indicators? A regional comparison of the climatic influence on Scots pine growth in Sweden. Can J For Res 32:1400-1410
Linkevičienė R, Taminskas J, Mažeikis A (2008) Simple method of modelling of bog lake's water level fluctuation: case study of Rèkyva lake. Anthropogenic Nat Transform Lakes 2:9598

MacDonald GM, Beilman DW, Kremenetski KV, Sheng Y, Smith LC, Velichko AA (2006) Rapid early development of circumarctic peatlands and atmospheric $\mathrm{CH}_{4}$ and $\mathrm{CO}_{2}$ variations. Science 314:285-288. doi:10.1126/science.1131722

Mažeika J, Guobytė R, Kibirkštis G, Petrošius R, Skuratovič Ž, Taminskas J (2009) The use of carbon-14 and tritium for peat and water dynamics characterizations: case of Čepkeliai peatland, Southeastern Lithuania. Geochronometria 34:4148

Mérian P (2012) POINTER and DENDRO - Two applications under R software for analyzing tree response to climate using dendroecological approach. Revue For Fr 64:789-798

Pärn H (2009) Temporal history of relationships between Scots pine (Pinus sylvestris L.) growth and mean monthly temperatures. Baltic For 15:48-57

Pikšrytė R (1996) Dendrochronological study on palaeowoodland dynamics in a Western Lithuanian peat bog. Geochronometria 13:203-214

Povilaitis A, Taminskas J, Gulbinas Z, Linkevičienė R, Pileckas M (2011) Lietuvos šlapynès ir jų vandensauginė reikšmė [Lithuanian wetlands and their water protective importance], 978-9955-609-55-1GPS, Vilnius, Lithuania

Poyatos R, Martínez-Vilalta J, Cermák JR, Ceulemans R, Granier A, Irvine J, Köstner B, Lagergren F, Meiresonne L, Nadezhdina N, Zimmermann R, Llorens P, Mencuccini M (2007) Plasticity in hydraulic architecture of Scots pine across Eurasia. Oecologia 153:245-259. doi:10.1007/ s00442-007-0740-0

Price JS, Schlotzhauer SM (1999) Importance of shrinkage and compression in determining water storage changes in peat: the case of a mined peatland. Hydrol Process 13:2591-2601

Pukienè R (2001) Natural changes in bog vegetation reconstructed by sub-fossil tree remnant analysis. Biologija 2:111-113

Rinn F (2003) TSAP-Win user reference manual. Rinntech, Heidelberg

Smiljanić M, Seo J-W, Läänelaid A, van der Maaten-Theunissen M, Stajić B, Wilmking M (2014) Peatland pines as a proxy for water table fluctuations: disentangling tree growth, hydrology and possible human influence. Sci Total Environ 500-501:52-63

Taminskas J, Linkevičienė R, Mažeika J, Kibirkštis G (2008) The impact of global climate change for hydrometeorological conditions of čepkeliai peatland: the elements of vertical water cycle. Ann Geophys 40:50-60

Vitas A (2004) Dendroclimatological research if Scots pine (Pinus sylvestris L.) in the Baltic coastal zone of Lithuania. Baltic For 10:65-71

Vitas A, Erlickyte R (2007) Influence of droughts to the radial growth of Scots pine (Pinus sylvestris L.) at different site conditions. Baltic For 13:10-16

Waddington JM, Morris PJ, Kettridge N, Granath G, Thompson DK, Moore PA (2014) Hydrological feedbacks in northern peatlands. Ecohydrology. doi:10.1002/eco.1493

Wigley TML, Briffa KR, Jones PD (1984) On the average value of correlated time-series, with applications in dendroclimatology and hydrometeorology. J Clim App1 Meteorol 23:201-213 